\title{
ČIMBENICI KRETANJA CIJENA STAMBENIH NEKRETNINA U HRVATSKOJ
}

\section{FACTORS INVOLVED IN THE MOVEMENTS OF RESIDENTIAL REAL ESTATE PRICES IN CROATIA}

SAŽETAK: Cilj ovoga rada je identificirati i istražiti ključne čimbenike kretanja indeksa cijena stambenih nekretnina u Hrvatskoj. Ključna metodološka novina ovoga istraživanja je procjena utjecaja programa subvencioniranja stanova i izrazito niskih kamatnih stopa na deviznu štednju na stambeno tržište. Analiza je odvojeno provedena na sva četiri indeksa cijena stambenih nekretnina pomoću kvartalnih podataka u razdoblju od 2003q1 do 2019q2. Rezultati su ukazali kako postoje razlike u čimbenicima koji objašnjavaju kretanje cijena stambenih nekretnina u Zagrebu u odnosu na Jadran i Hrvatsku ostalo. U razdoblju nakon pokretanja programa subvencioniranja stambenih kredita, identificiran je statistički značajan porast cijena stambenih nekretnina u Zagrebu koji se nije mogao objasniti ostalim varijablama u modelu. Statistički značajan utjecaj seljenja spekulativnog kapitala iz devizne štednje na stambeno tržište nije pronađen. Utjecaj varijable loših kredita najbolje objašnjava kretanje cijena stambenih nekretnina na Jadranu i ostatku Hrvatske, BDP je koristan za predviđanje cijena na Jadranu, Zagrebu i ukupno za cijelu Hrvatsku. Sva četiri indeksa su autokorelirana odnosno postoji snažan empirijski dokaz postojanja adaptivnih očekivanja na tržištu.

KLJUČNE RIJEČI: stambeno tržište, subvencije, rast cijena stanova, ponuda i potražnja za stanovima

ABSTRACT: This paper aims to identify and research the key factors involved in the movements of residential real estate index prices in Croatia. A key methodological novelty of this research is the assessment of the impact of housing subsidy programs and extremely low interest rates on foreign currency savings on the housing market. The analysis was conducted separately on all four residential property price indices using quarterly data for the period from 2003q1 to 2019q2. The results indicated that there are differences in the factors that explain the movement of residential real estate prices in Zagreb compared to the

Prof. dr. sc. Josip Tica, Ekonomski fakultet Sveučilišta u Zagrebu, Trg J. F. Kennedyja 6, 10000 Zagreb, e-mail: jtica@efzg.hr 
Adriatic and Croatia elsewhere. In the period after the launch of the housing loan subsidy program, a statistically significant increase in residential real estate prices in Zagreb was identified, which could not be explained by other variables in the model. No statistically significant impact of the movement of speculative capital from foreign currency savings on the housing market was found. The influence of the bad loans variable best explains the movement of residential real estate prices in the Adriatic and the rest of Croatia, GDP is useful for forecasting prices in the Adriatic, Zagreb and in total for the whole of Croatia. All four indices are autocorrelated, ie there is strong empirical evidence for the existence of adaptive expectations in the market.

KEYWORDS: housing market, subsidies, rising apartment prices, supply and demand for apartments

\section{UVOD}

Cilj ovoga rada je analizirati utjecaj standardnih ekonomskih fundamenata na kretanje cijena hrvatskih stambenih nekretnina. Ključni doprinos rada je kontroliranje procjene za utjecaj programa stambenih subvencija i utjecaj rekordno niskih prinosa na štednju u bankama na kretanje cijena na stambenom tržištu.

Početkom svjetske gospodarske recesije krajem 2008. godine došlo je do ubrzanog urušavanja cijena stambenih nekretnina u Hrvatskoj. Kriza stambenog tržišta je rezultirala rastom udjela loših kredita (NPL) u bilancama poslovnih banaka, koji se tijekom šestogodišnje krize popeo na preko $60 \%$ u sektoru građevinarstva odnosno preko $40 \%$ u sektoru poslovanja nekretninama. Događanja na stambenom tržištu i tržištu nekretnina' (građevinarstvo, posredovanje nekretninama) značajno su otežala izlazak iz recesije hrvatskog gospodarstva i doprinijeli dužini recesije koja je potrajala bitno duže od svih usporedivih tranzicijskih zemalja.

Razumijevanje svih procesa na stambenom tržištu je nužno kako bi se spriječilo možebitno nastajanje tržišnih balona koji bi svojim moguću pucanjem ponovno mogli ugroziti oporavak hrvatskog gospodarstva. Udio sektora građevinarstva i posredovanja nekretninama u bruto dodanoj vrijednosti Hrvatske je između 10-20 \% i u biti bez održivog razvoja ova dva sektora nemoguće je očekivati zdrav i održiv rast ne samo financijskog sektora, nego i cjelokupnog gospodarstva. Navedeni zaključak još dodatno pojačava činjenica kako prema podacima FINA-e skoro $80 \%$ materijalne imovine nefinancijskih poduzeća u Hrvatskoj u biti predstavljaju zgrade, zemljišta i ulaganja u nekretnine (Tica i Šagovac, 2019).

Imajući u vidu trenutno usporavanje gospodarstva uvjetovano mjerama borbe protiv koronavirusa, izvjesno je kako identificiranje determinanti kretanja cijena stanova može biti korisno i za predviđanje reakcije tržišta nekretnina, građevinske industrije i cijena stanova tijekom trajanja mjera fizičkog razdvajanja, poremećaja u turističkim putovanjima i posljedičnog pada poslovne aktivnosti.

Stambeno tržište je najpopularniji segment tržišta nekretnina, ali treba imati u vidu da je poslovna aktivnost prije krize bila izrazito snažna u maloprodaji (retail), poslovnim nekretninama (office) i turizmu (hotel and 2nd home). 
Procjena utjecaja je napravljena pomoću metode najmanjih kvadrata na način da je procijenjen čitav niz regresijskih modela u kojima je indeks cijena stambenih nekretnina (ICSN) regresiran na osam ekonomskih varijabli koje aproksimiraju kretanje ponude i potražnje na stambenom tržištu. Čimbenici potražnje su aproksimirani BDP-om, kamatnim stopama na stambene kredite, ukupnom masom stambenih kredita i kretanjem deviznih depozita te kamatnih stopa na devizne depozite. Na strani ponude ključne varijable koje se koriste u analizi su podaci o broju izdanih građevinskih dozvola, troškovima građevinskih radova i udjelu loših kredita (NPL) poslovnih banaka.

Ključan znanstveni doprinos rada se iščitava iz procjene utjecaja efekta preslagivanja portfelja i utjecaja razdoblja uvođenja subvencioniranja stambenih kredita na kretanje cijene stanova. Navedena dva efekta bi prema teoriji mogla biti odgovorna za snažno ubrzanje rasta cijena stambenih nekretnina nakon 2017. godine koje ne možemo povezati s klasičnim ekonomskim fundamentima koji su dosada korišteni u procjenama funkcija ponude i potražnje. Povrh toga, novina rada je da se funkcije procjenjuju pomoću novog indeksa cijena stambenih nekretnina koji je nedavno ažuriran unazad do 2002. godine. Prednost navedenog indeksa u odnosu na HNB-ov Hedonički indeks cijena nekretnina je činjenica što se računa na temelju kompletne populacije postignutih kunskih cijena stanova na temelju podataka Porezne uprave dok su dosadašnje studije uglavnom bile bazirane na indeksima cijena koji su se bazirali na uzroku i/ili eurskim cijenama. Povrh toga, korištenje navedenog indeksa nam omogućuje odvojene procjene čimbenika cijena stanova za Jadran, Zagreb, Hrvatsku i Hrvatsku ostalo.

Rezultati istraživanja ukazuju kako su BDP, adaptivna očekivanja i stambeni krediti ključni za objašnjavanje kretanja cijena na stambenom tržištu u Hrvatskoj. Za Zagreb je procjena pokazala kako je nakon uvođenja programa subvencija stambenih kredita došlo do dodatnog porasta cijena stambenih nekretnina koji nije mogao biti objašnjen ostalim varijablama u modelu. Uspoređujući relativnu veličinu koeficijenata, najveći utjecaj je procijenjen za binarnu varijablu u vremenu nakon pokretanja programa subvencioniranja stambenih kredita. Loši krediti su se pokazali značajnim u jadranskoj Hrvatskoj i ostatku zemlje. Robusnost modela je dobra s obzirom na broj opservacija na kojima je model procijenjen odnosno nabrojene varijable su statistički značajne i imaju teoretski očekivani predznak u većini procjena.

Rad je podijeljen na šest dijelova. Nakon uvoda slijedi poglavlje koje analizira događanja na tržištu s posebnim naglaskom na trendove nakon svjetske financijske krize. U trećem dijelu rada nudi se pregled literature. Četvrti dio rada donosi uvid u metodologiju i podatke. Peti dio rada donosi interpretaciju rezultata, a posljednji šesti dio rada je zaključak.

\section{DOGAĐANJA NA TRŽIŠTU I TEORETSKI MODEL}

Indeks cijena stambenih nekretnina (ICSN) je nakon snažnog pada koji je uslijedio tijekom svjetske gospodarske krize prestao padati u prvom kvartalu 2015. godine, točno jedan kvartal nakon prve pozitivne stope rasta BDP-a (Grafikon 1). Nakon toga je ICSN, kao i većina njegovih podindeksa stagnirao sve do početka 2017. godine kada je paralelno sa usporavanjem ekonomskog rasta (stopa rasta BDP-a od tada polako opada) znatno ubrzao svoj rast. 
Grafikon 1: Indeks cijena stambenih nekretnina u Hrvatskoj (ICSN, 2015=100)

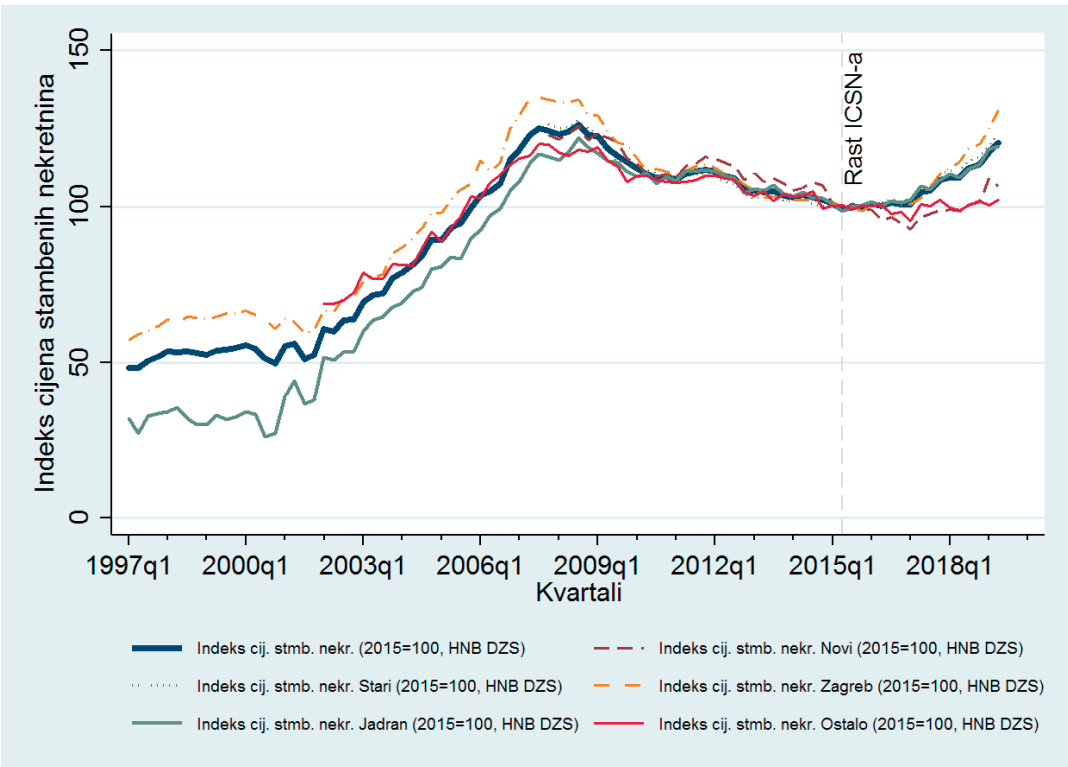

Napomena: ICSN računa DZS prema podacima Porezne uprave na temelju cijena stanova izraženih u HRK i pomoću metodologije hedoničkogindeksa cijenakojijeizradioHNB (KunovaciKotarac, 2019). Podacizarazdoblje prije 2002. su preuzeti i prilagođeni iz ranijeg hedoničkog indeksa koji je radio HNB (Kunovac, Đozović, Lukinić i Pufnik, 2008). Izvor: HNB i DZS (2019).

Međutim, kao što je vidljivo iz podataka, navedeni rast nije homogen kada se pogledaju sve komponente ICSN-a. Državni zavod za statistiku (DZS) računa ukupno šest indeksa cijena stambenih nekretnina: ukupno za Hrvatsku, zatim za Zagreb, Jadran i ostatak zemlje te dva odvojena indeksa za cijelu zemlju od kojih jedan prati cijene novosagrađenih stanova, a drugi cijene stanova koji ne spadaju u novosagrađene stanove (stari ili rabljeni stanovi).

Grafikon 2 prikazuje prosječne stope rasta na godišnjoj razini (kvartal u odnosu na istoimeni kvartal prethodne godine) od prvog kvartala 2015. godine. Kao što je vidljivo iz prikaza, stope rasta su različite među kategorijama. Iako u prosjeku ICSN za cijelu Hrvatsku raste nešto sporije od $3 \%$ u promatranom razdoblju, postoje komponente indeksa koje i dalje imaju negativnu stopu rasta u promatranom razdoblju i to novi stanovi i stambeni prostori izvan Zagreba i izvan obalnih jedinica lokalne samouprave (tzv. Hrvatska ostalo). Kao što je razvidno iz grafikona, najbrže prosječne stope rasta bilježi Grad Zagreb i to preko $4 \%$, a nakon toga cijene rabljenih stanova u Hrvatskoj s prosječnom stopom rasta od približno $3,7 \%$.

Navedena dinamika je izrazito neobična u odnosu na cjelokupno razdoblje od kada imamo indeks cijena na raspolaganju. $\mathrm{U}$ razdoblju prije 2008. godine upravo su cijene stanova na Jadranu dominirale indeksom i najbrže rasle, a sada Zagreb dominira uzorkom. Navedeno se događa u uvjetima razvoja sektora kratkoročnog najma u Zagrebu, što je djelomično posljedica snažnog rasta cijena najma u Zagrebu, ali i u gradovima na obali².

2 Objavljeni podaci DZS-a ne pokrivaju podatke za cijene najma stambenog prostora, tako da je trend iden- 
Grafikon 2: Indeks cijena stambenih nekretnina - prosječne međugodišnje stope rasta nakon prvog kvartala 2015. godine.

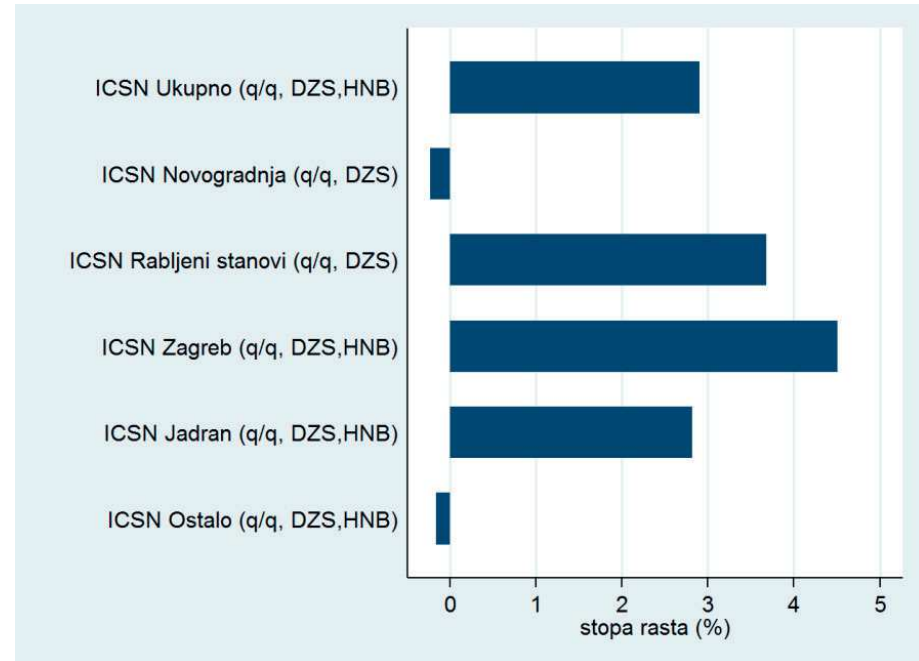

Napomena: stope rasta su izračunate kao sezonska (kvartali) log-diferencija.

Izvor: DZS (2019)

Ustrajan pad cijena novosagrađenih stanova je u svakom slučaju neočekivan, ali podaci ukazuju kako do kraja 2019. nije došlo do oporavka u ovome segmentu tržišta. Dvije su moguće hipoteze koje mogu objasniti ovakvu razinu heterogenosti između rabljenih i novih stanova. Prvo, sustav subvencija stavlja administrativne zapreke za kupovinu stanova koji nisu u uporabi tako da je ovaj segment tržišta uglavnom izvan dometa poticaja subvencioniranih kredita. Drugo, oporavak tržišta nekretnina se poklopio s padom udjela loših kredita u bilancama poslovnih banaka odnosno rasprodaja potraživanja po lošim kreditima se odvijala paralelno s oporavkom tržišta (Grafikon 4) tako da je otvoreno pitanje u kojoj mjeri su navedeni formalno novi stanovi djelovali na kretanje indeksa cijena novih stanova.

Kada govorimo o Hrvatskoj ostalo, tu se radi o jedinicama lokalnih samouprava (JLS) koje nemaju obalu i koji se ne odnose na Grad Zagreb. Od ekonomski propulzivnijih regija tu možemo spomenuti unutrašnjost Istre, Zagrebačku županiju i sjeverozapadne županije općenito. Prostor Banovine, Korduna, Like, Gorskog kotara i slavonskih županija u biti predvodi ljestvicu po jeftinoći stambenih nekretnina ${ }^{3}$. Spor oporavak cijena stambenih nekretnina u ovome području posljedica je cijeloga niza čimbenika od neujednačenog regionalnog razvoja, preko deindustrijalizacije pa sve do demografskog pražnjenja prostora.

tificiran na temelju podataka za tražene cijene dostupne u bazi podataka oglasnika Njuškalo (2017).

Objavljeni podaci DZS-a ne pokrivaju podatke za cijene stambenog prostora po gradovima, tako da je trend identificiran na temelju podataka za tražene cijene dostupne u bazi podataka oglasnika Njuškalo (2017). 


\section{PREGLED LITERATURE}

U teoretskom smislu najutjecajnije istraživanje u pogledu funkcioniranja tržišta nekretnina je svakako DiPasquale Wheaton (1992) model u kojem su postavljeni osnovni elementi funkcija ponude i potražnje na tržištu nekretnina, koje u kombinaciji s troškom korištenja nekretnina možemo adaptirati za analizu stambenog tržišta. Osnovni pristup DW modela (1992) se bazira na odvojenom procjenjivanju funkcije potražnje uz pretpostavku fiksne ponude u kratkom roku te odvojenog procjenjivanja funkcije ponude u kojoj je zavisna varijabla novosagrađeni broj kvadrata, a nezavisna varijabla je cijena stambenih nekretnina modelirana u funkciji potrošnje. U ekonometrijskom smislu radi se o svojevrsnom two-stage-least-square pristupu.

U empirijskim radovima u biti postoje dva pristupa modeliranju cijena stambenih nekretnina. Prvi pristup se bazira na formiranju funkcija ponude i potražnje te izvodu reducirane funkcije koja se procjenjuje (Quigley, 1999; Égert and Mihaljek, 2007; Coleman et al., 2008; Clark and Coggin, 2011). Drugi pristup se bazira na odnosu troška vlasništva stana i cijene najma te se tržište modelira pomoću odnosa ova dva parametra (Poterba, 1984; Gallin, 2006; Holly et al., 2010). Uobičajeno je u oba pristupa da se model procjenjuje na način da je zavisna varijabla cijena nekretnina, a nezavisne varijable su dohodak, kamatna stopa, stambeni krediti, populacija, uvjeti kreditiranja i promjene u neto imovini sektora kućanstava (efekt bogatstva).

Iako postoji veliki broj radova koji su modelirali determinante cijena stambenih nekretnina, kada govorimo o Hrvatskoj, zbog problema s dostupnošću podatka, većina studija je rađena kao panel analiza tranzicijskih ili euro zemalja (Vizek, 2010; Vizek i Posedel, 2009; Dajčman, 2019). Kada govorimo o analizi vremenskih serija, tada svakako treba krenuti od rada Slišković (2019) koji se najbliže približio idealnoj procjeni DiPasquale i Wheaton (1992) modela na hrvatskom stambenom tržištu i Tice (2004) u kojem je napravljena jedna od ranijih verzija procjene reducirane funkcije cijena stambenih nekretnina.

Ključan doprinos ovoga rada je istraživanje utjecaja pada kamatnih stopa na štedne devizne depozite i utjecaja razdoblja u kojem je uveden program subvencija stambenih kredita na stambeno tržište. Osim navedenog, u odnosu na istraživanje od Slišković (2016, 2019) postoje još dvije različitosti. Prvo, u ovome radu se koristi indeks cijena stambenih nekretnina (ICSN) u cijelom razdoblju nakon prvog kvartala 2002. godine. Navedeni indeks je naslijedio hedonički indeks cijena nekretnina te je nedavno objavljen i za razdoblje od 2002. do 2008. Drugo, ekonometrijski model je pojednostavljen i ne slijedi doslovno DiPasquale i Wheaton (1992) pristup. Također, važno je istaknuti kako su zasebno analizirani regionalni indeksi i nacionalni prosječan indeks cijena. Povrh toga, analiza je fokusirana na utjecaj kretanja loših kredita na cijene stambenih nekretnina koji su se pokazale značajnim prediktorom cijena u određenim regijama Hrvatske.

\section{METODOLOGIJA I PODACI}

Tablica 1 prikazuje opis izvornih podataka koji su korišteni u analizi i iz kojih su konstruirane međugodišnje stope rasta. Korišteni su podaci iz Eurostata, Hrvatske narodne

banke i Državnog zavoda za statistiku. Indeks cijena stambenih nekretnina je preuzet od 
Tablica 1: Popis korištenih izvornih podataka s opisom modifikacija, izvora i vremenskog razdoblja za koje su dostupni podaci

\begin{tabular}{|c|c|c|c|}
\hline Varijabla & Izvor & $\begin{array}{l}\text { Vremensko } \\
\text { razdoblje }\end{array}$ & $\begin{array}{c}\text { Modifikacije } \\
\text { izvornih podatka u } \\
\text { ekonometrijskoj analizi }\end{array}$ \\
\hline $\begin{array}{l}\text { Indeks cijena stam- } \\
\text { benih nekretnina } \\
\text { Ukupno, Zagreb, } \\
\text { Hrvatska i ostalo }\end{array}$ & $\begin{array}{l}\text { Državni zavod za } \\
\text { statistiku, po staroj } \\
\text { metodologiji He- } \\
\text { donički indeks od } \\
\text { hrvatske narodne } \\
\text { banke }\end{array}$ & $\begin{array}{l}\text { 1997q1(2002q1)- } \\
2019 q 3\end{array}$ & $\begin{array}{l}\text { Logaritam međugodišnje } \\
\text { stope rasta (t/t-4) }\end{array}$ \\
\hline $\begin{array}{l}\text { Indeks cijena stam- } \\
\text { benih nekretnina } \\
\text { novi i stari stanovi }\end{array}$ & $\begin{array}{l}\text { Državni zavod za } \\
\text { statistiku }\end{array}$ & $2007 q 4-2019 q 3$ & $\begin{array}{l}\text { Logaritam međugodišnje } \\
\text { stope rasta (t/t-4) }\end{array}$ \\
\hline $\begin{array}{l}\text { BDP u cijenama } \\
\text { prethodne godine u } \\
\text { cijenama } 2010 .\end{array}$ & $\begin{array}{l}\text { (nama_10_gdp) } \\
\text { Eurostat }\end{array}$ & $2000 q 1-2019 q 3$ & $\begin{array}{l}\text { Logaritam međugodišnje } \\
\text { stope rasta }(\mathrm{t} / \mathrm{t}-4)\end{array}$ \\
\hline $\begin{array}{l}\text { Indeks građevin- } \\
\text { skih radova }\end{array}$ & $\begin{array}{l}\text { (sts_copi_q) Eu- } \\
\text { rostat }\end{array}$ & $2000 q 1-2019 q 2$ & $\begin{array}{l}\text { Logaritam međugodišnje } \\
\text { stope rasta (t/t-4) }\end{array}$ \\
\hline $\begin{array}{l}\text { Odobrenja za } \\
\text { građenje }\end{array}$ & $\begin{array}{l}\text { (sts_copi_q) Eu- } \\
\text { rostat }\end{array}$ & 2000q1-2019q3 & $\begin{array}{l}\text { Logaritam međugodišnje } \\
\text { stope rasta (t/t-4), HP } \\
\text { filter ili pomični prosjek }\end{array}$ \\
\hline $\begin{array}{l}\text { Kamatna stopa na } \\
\text { dugoročne stambe- } \\
\text { ne kredite u euru }\end{array}$ & $\begin{array}{l}\text { (h-g2b, po staroj } \\
\text { metodologiji: Ta- } \\
\text { blica G2), Hrvats- } \\
\text { ka narodna banka } \\
\end{array}$ & $\begin{array}{l}\text { 2002M1(2011M12)- } \\
\text { 2019M12 }\end{array}$ & $\begin{array}{l}\text { Pretvoreno u kvartalne } \\
\text { podatke po prosjeku, } \\
\text { logaritam razina }\end{array}$ \\
\hline $\begin{array}{l}\text { Stambeni krediti } \\
\text { stanje (kunski i } \\
\text { eurski) }\end{array}$ & $\begin{array}{l}\text { (h-d5, po staroj } \\
\text { metodologiji: Ta- } \\
\text { blica D5), Hrvats- } \\
\text { ka narodna banka }\end{array}$ & $\begin{array}{l}\text { 2002M1(2006M6)- } \\
\text { 2019M12 }\end{array}$ & $\begin{array}{l}\text { Pretvoreno u kvartalne } \\
\text { podatke po zadnjoj } \\
\text { opservaciji, logaritam } \\
\text { međugodišnje stope rasta }\end{array}$ \\
\hline $\begin{array}{l}\text { Devizni depoziti } \\
\text { (prosjek za sve } \\
\text { depozite) }\end{array}$ & $\begin{array}{l}\text { (hd-1 Bilanca } \\
\text { poslovnih banaka), } \\
\text { Hrvatska narodna } \\
\text { banka }\end{array}$ & 2002M1-2019M12 & $\begin{array}{l}\text { Pretvoreno u kvartalne } \\
\text { podatke po zadnjoj } \\
\text { opservaciji, logaritam } \\
\text { međugodišnje stope } \\
\text { rasta }\end{array}$ \\
\hline $\begin{array}{l}\text { Kamatna stopa na } \\
\text { devizne depozite }\end{array}$ & $\begin{array}{l}\text { (G5c: Kamatne } \\
\text { stope kreditnih in- } \\
\text { stitucija na devizne } \\
\text { depozite i kredite } \\
\text { (stanja)), Hrvatska } \\
\text { narodna banka }\end{array}$ & 2011M12-2019M12 & $\begin{array}{l}\text { Pretvoreno u kvartalne } \\
\text { podatke po zadnjoj } \\
\text { opservaciji, logaritam } \\
\text { razina }\end{array}$ \\
\hline $\begin{array}{l}\text { Ukupni krediti iz } \\
\text { kategorije B i C } \\
\text { (NPL-Loši krediti) } \\
\end{array}$ & $\begin{array}{l}\text { Hrvatska narodna } \\
\text { banka }\end{array}$ & $1999 q 2-2019 q 2$ & $\begin{array}{l}\text { Logaritam međugodišnje } \\
\text { stope rasta }(\mathrm{t} / \mathrm{t}-4)\end{array}$ \\
\hline
\end{tabular}

Izvor: autor. 
Državnog zavoda za statistiku (2019) za razdoblje nakon 2002. i od HNB-a (2019) za razdoblje od 1997. BDP u cijenama prethodne godine u cijenama bazne 2010. godine u HRK, broj odobrenja za građenje i indeks cijena u građevinarstvu preuzeti su od Eurostata (2019). Udio loših kredita (krediti kategorije B i C) u poslovnim bankama, iznos deviznih depozita, masa izdanih stambenih kredita, kamatna stopa na stambene kredite i kamatna stopa na devizne depozite preuzeti su od HNB-a (2019).

Vremenska serija za iznos stambenih kredita i kamatnih stopa na stambene kredite je doživjela promjene u metodologiji tako da su za razdoblje prije lipnja 2006. za stambene kredite, a prije prosinca 2011. za kamatne stope na stambene kredite korištene serije vođene po staroj metodologiji. Isto vrijedi i za Indeks cijena stambenih nekretnina koji je prije 2002. godine računat pomoću različitog uzorka pod nazivom Hedonički indeks cijena nekretnine od strane HNB-a. ${ }^{4}$ Kako se dvije metodologije djelomično vremenski preklapaju, a ekonometrijska analiza je rađena na međugodišnjim stopama rasta, serije su jednostavno pridružene.

Sve četiri serije preuzete iz HNB-a objavljene su na mjesečnoj frekvenciji, tako da je bilo nužno pretvoriti podatke u kvartalne frekvencije. Pretvorba je napravljena pomoću zadnje opservacije u kvartalu za seriju stambenih kredita i deviznih depozita, a pomoću prosjeka kvartala za serije kamatnih stopa na stambene kredite i kamatnih stopa na devizne depozite.

Sve serije podataka s izuzetkom kamatnih stopa desezonirane su sezonskim diferenciranjem (4 vremenska pomaka) njihovih logaritama i pomnožene sa 100. Na taj način smo u biti dobili međugodišnje kvartalne logaritamske stope rasta odnosno svaki broj predstavlja postotnu promjenu varijable u odnosu na istoimeni kvartal prethodne godine. Nakon sezonskog diferenciranja gotovo sve varijable su se pokazale stacionarnima prema konvencionalnim testovima jediničnog korijena. ${ }^{5}$ Korištenjem sezonskog log-diferenciranja smo u biti na vrlo jednostavan način riješili problem sezonalnosti i stacionarnosti promatranih varijabli.

Grafikon 3 prikazuje međugodišnje kvartalne stope rasta BDP-a, kamatne stope na stambene kredite, ukupne mase stambenih kredita i mase deviznih depozita. Sve četiri varijable su uparene s međugodišnjom stopom rasta indeksa cijena stambenih nekretnina za Hrvatsku. Tri vertikalne linije povučene okomito na vremenskoj osi grafikona predstavljaju tri vala stambenih subvencija za mlade koji su se odvijali u rujnu 2017., 2018. i 2019. godine, a koji su u analizi modelirani pomoću binarne varijable.

Grafikon 4 prikazuje međugodišnje kvartalne stope rasta kamatnih stopa na devizne depozite, broj izdanih odobrenja za građenje, indeksa građevinskih troškova i udjela loših kredita u kreditnim plasmanima.

Procjena ekonometrijskog modela determinacije cijena stambenih nekretnina bazirana je na procjeni reduciranog modela koji na lijevoj strani ima cijene stambenih nekretnina, a na desnoj čimbenike potražnje i ponude. Izvod započinjemo s funkcijom potražnje za stambenim jedinicama koja je funkcija BDP-a i troška vlasništva stambene jedinice.

$$
I C S N_{t}=\alpha+\beta_{1} B D P_{t}+\beta_{2} U_{t}+\varepsilon_{-} t
$$

\footnotetext{
$4 \quad$ Hedonički indeks cijena nekretnina je računat na temelju baze podataka Burze nekretnina, dok se Indeks cijena stambenih nekretnina računa na temelju baze podataka Porezne uprave. Podatke za razdoblje prije 2002. godine smo računali samo u deskriptivnoj analizi u drugom poglavlju i vizualnoj prezentaciji podataka, ali ne i u ekonometrijskoj analizi.

5 Podaci o rezultatima testova jediničnog korijena su dostupni od autora na zahtjev.
} 
Grafikon 3: Međugodišnje stope rasta ICSN-a, BDP-a, kamatnih stopa na stambene nekretnine i deviznih depozita u poslovnim bankama

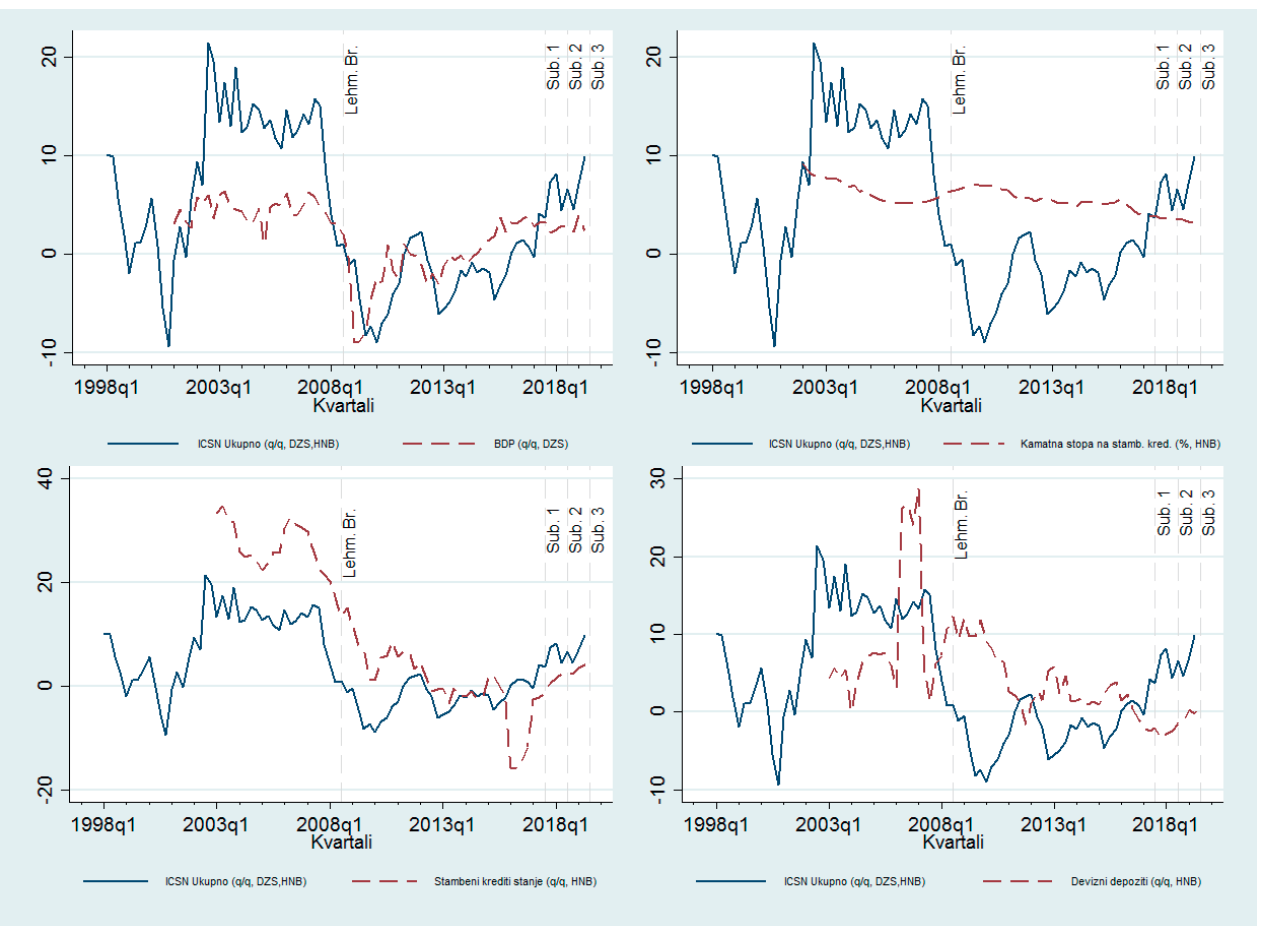

Napomena: ICSN prije 2002. je u biti Hedonički indeks nekretnina HNB-a. Izvor: HNB (2019), DZS (2019) i Eurostat (2019).

Prema teoriji, trošak vlasništva (U) se sastoji od kamatne stope (pasivne ili aktivne ovisno o načinu stjecanja nekretnine) i očekivanog pada cijena nekretnina tijekom posjedovanja nekretnine. Ukoliko potencijalni kupci očekuju pad cijena nekretnina navedeno će percipirati kao dodatan trošak vlasništva stana povrh kamatne stope koju će plaćati banci u slučaju stambenog kredita ili kamatne stope koju će izgubiti u banci ako kupuju stan svojim novcem (oportunitetni trošak). Sukladno teoriji, trošak vlasništva je modeliran kao razlika kamatne stope na stambene kredite i vremenskog pomaka pomičnog prosjeka ICSN-a tijekom prethodna četiri kvartala (MICSN). ${ }^{6}$ Pomični prosjek u biti predstavlja aproksimaciju adaptivnih očekivanja promjene cijena.

$$
U_{t}=I N T R A T E_{t}-\operatorname{MICSN}_{t-1}
$$

Model potražnje povrh toga proširujemo s četiri dodatna čimbenika te je indeks cijena nekretnina regresiran i na binarnu (indikatorsku, dummy) varijablu za subvencije za stambene kredite za mlade (D), na ukupnu masu izdanih stambenih kredita (STAMKRED),

6 Odabran je pomični prosjek od 4 kvartala zbog pretpostavke da se radi o godišnjem pomaku s obzirom na percepciju godišnjih stopa rasta. Kako bi se provjerila robusnost ove pretpostavke ekonometrijski modeli su procijenjeni bez pomičnog prosjeka s pomakom od samo jednog kvartala. 
Grafikon 4: Međugodišnje stope rasta ICSN-a, kamatnih stopa na devizne depozite, indeksa građevinskih radova, izdanih odobrenja za građenje i udjela loših kredita u poslovnim bankama

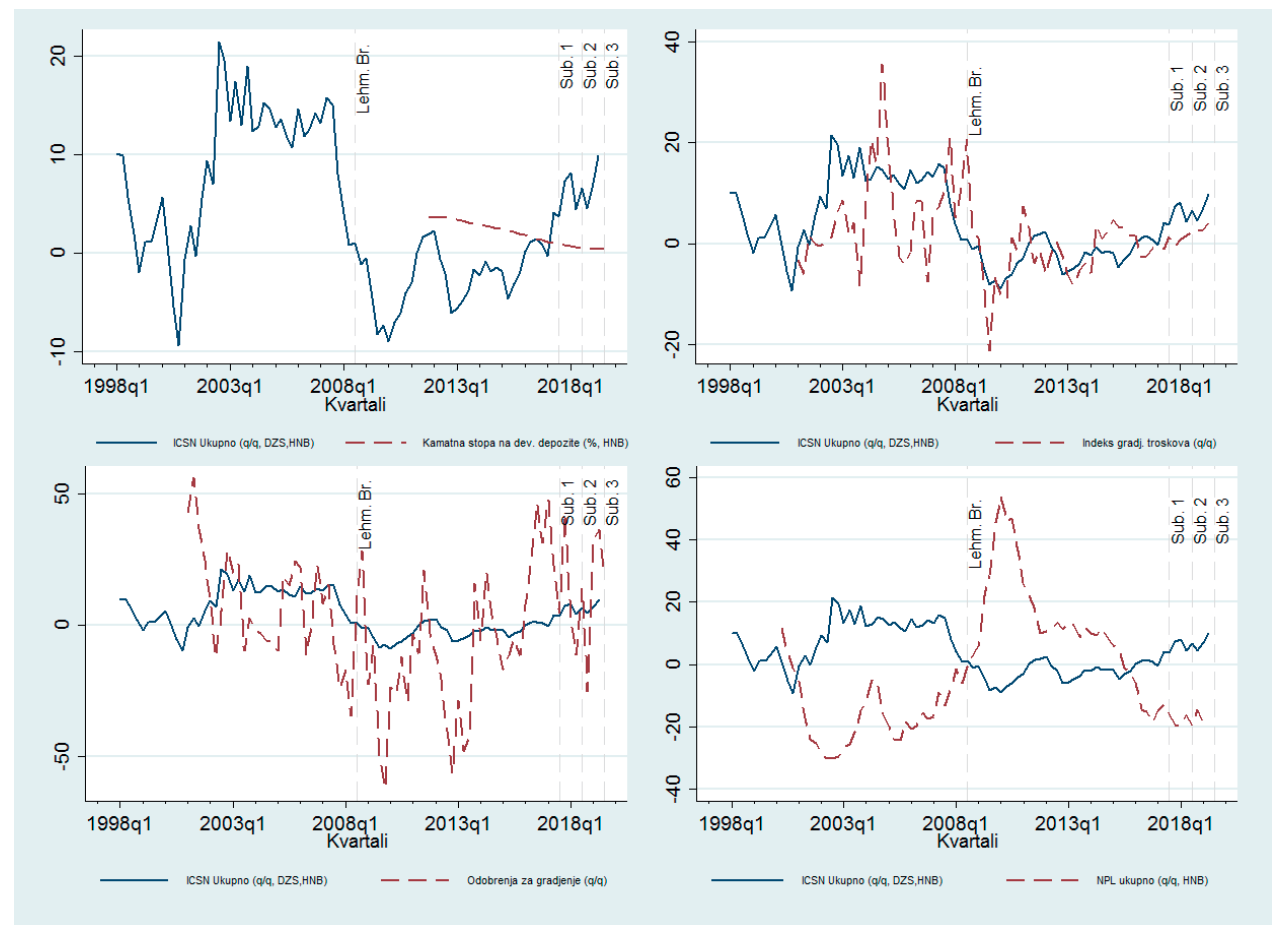

Napomena: ICSN prije 2002. je u biti Hedonički indeks nekretnina HNB-a.

Izvor: HNB (2019), DZS (2019) i Eurostat (2019).

ukupan iznos deviznih depozita u poslovnim bankama (DEVDEPOZIT) i kamatnu stopu na devizne depozite (INTDEVDEP).

$\mathrm{Na}$ strani ponude korištene su tri ekonomske varijable. Indeks troškova građenja (CONSTRCOST), broj izdanih odobrenja za građenje (BUILDPERM) i udio loših kredita u poslovnim bakama (NPL). Zbog iznimno velike kolebljivosti indikatora BUILDPERM, u ekonometrijskom modelu korištena je serija zaglađena pokretnim prosjekom prethodna četiri kvartala (MBUILDPERM) i serija zaglađena HP filterom (HPBUILDPERM).

Osnovni model je za početni ekonometrijski model procijenjen pomoću ove jednadžbe (Tablica 1 - stupac 1$)$.

$$
\begin{gathered}
\text { ICSN }_{t}=\alpha+\beta_{1} \text { BDP }_{t}+\beta_{2} \text { INTRATE }_{t}-\beta_{3} \text { MICSN }_{t-1}+\beta_{4} \text { DEVDEPOZIT }_{t}+\beta_{5} D_{t} \\
+\beta_{6} \text { CONSTRCOST }_{\mathrm{t}}+\beta_{7} \text { MBUILDPERM }_{\mathrm{t}}+\beta_{8} \text { NPL }_{\mathrm{t}}+\varepsilon_{-} t
\end{gathered}
$$

U provjeri robusnosti ovoga ekonometrijskog modela umjesto iznosa ukupne devizne štednje (DEVDEPOZIT) korištena je i kamatna stopa na devizne depozite (INTDEVDEP). Unatoč problemima s brojem opservacija nismo ignorirali kamatne stope u istraživanju jer je varijabla deviznih depozita, kao i kamatnih stopa na devizne depozite iznimno važna za aproksimaciju utjecaja kratkoročnog najma u turizmu na cijene stanova u Hrvatskoj (tzv. efekt portfelja odnosno bogatstva). 
Prema hipotezi restrukturiranja portfelja, u trenutku kada kamatna stopa na štedne depozite dosegne vrijednost koja je približno jednaka nuli, tada nastaje profitni motiv za ulaganje u alternativne investicijske prilike. Imajući u vidu kako se pad pasivnih kamatnih stopa na niske razine poklopio s rastom ICSN-a, moguće je kako špekulativno seljenje štednje iz poslovnih banaka na tržište nekretnina igra dodatnu ulogu u rastu ICSN-a. Upravo je i to razlog zašto smo stavili devizne depozite i kamatnu stopu na devizne depozite kao eksplanatorne varijable. Tablica $1 \mathrm{u}$ stupcu broj 2 prikazuje ekonometrijski model s kamatom na devizne depozite (INTDEVDEP) umjesto mase deviznih depozita.

Osim zamjene ukupne mase deviznih depozita s kamatnom stopom na devizne depozite, također je i trošak vlasništva nekretnina supstituiran s masom izdanih stambenih kredita kao indikatorom kreditne aktivnosti i jednostavnim AR(1) pomakom zavisne varijable kao aproksimacijom adaptivnih očekivanja. Tablica 1. u stupcima 3 i 4 prikazuje navedenu procjenu, s tim da je u stupcu 3 korištena devizna štednja, a u stupcu četiri kamatna stopa na deviznu štednju kao aproksimacija preslagivanja portfelja u zamci likvidnosti. Model je u tom slučaju opisan jednadžbom:

$$
\begin{gathered}
\text { ICSN }_{t}=\alpha+\beta_{0} \text { ICSN }_{t-1}+\beta_{1} \text { BDP }_{t}+\beta_{2} \text { STAMKRED }_{t}+\beta_{3} \text { DEVDEPOZIT }_{t}+\beta_{4} D_{t} \\
+\beta_{5} \text { CONSTRCOST }_{\mathrm{t}}+\beta_{6} \text { MBUILDPERM }_{\mathrm{t}}+\beta_{7} \text { NPL }_{\mathrm{t}}+\varepsilon_{-} t
\end{gathered}
$$

Navedene četiri procjene su nakon toga ponovljene s HP filterom izdanih odobrenja za građenje HPBUILDPERM umjesto pokretnog prosjeka MBUILDPERM (Tablica 1 - stupci 5 do 8). Ukupno je dakle napravljeno 8 različitih procjena utjecaja čimbenika ponude i potražnje za indeks cijena nekretnina. Kao zavisna varijabla korišten je indeks cijena stambenih nekretnina za cijelu RH (ICSN_uk), zatim za Zagreb (ICSN_zg), Jadran (ICSN_jadr) i na kraju za Hrvatsku ostalo.

\section{REZULTATI}

Ukupno je procijenjeno 32 ekonometrijska modela, osam procijenjenih modela za ICSN za Hrvatsku, osam za Zagreb, Jadran i za Hrvatsku ostalo. Rezultati su prikazani u tablicama na način da je osam procjena za svaki od četiri indeksa grupirano u zasebnu tablicu. Modeli s neparnom oznakom modela (1, 3, 5 i 7) procijenjeni su na 66 opservacija u razdoblju od 2003q1 do 2019q2. Modeli s parnim brojem u tablicama procijenjeni su na temelju 31 dostupne opservacije iz razloga što je u njima korištena varijabla za kamatne stope na devizne depozite za koju imamo dostupne podatke samo za razdoblje nakon prosinca 2011. godine. Sukladno tome, analiza je napravljena za 2011q4-2019q2.

Tablica 1 prikazuje osam regresijskih modela za Hrvatsku ukupno. Od svih varijabli koje su u procjenama bile statistički značajne, najrobusniji je rezultat za vremenski pomak zavisne varijable. Naime, vremenski pomak zavisne varijable je signifikantan u gotovo svim modelima, kao pokretni prosjek (MICSN) ili kao jednostavni vremenski pomak ICSN(t-1). Osim zavisne varijable, u svim modelima koji imaju 66 opservacija, BDP je statistički značajan i ima pozitivan efekt na kretanje cijena stambenih nekretnina u Hrvatskoj.

Procjene 2, 4, 6 i 8 imaju s desne strane varijablu kamatne stope na devizne depozite umjesto mase deviznih depozita, jer je za kamatnu stopu na devizne depozite dostupan manji broj opservacija odnosno samo 31 opservacija. U svim tako kratkih uzorcima, procjena 
Tablica 2: Sveobuhvatni regresijski model - Hrvatska ukupno

\begin{tabular}{|c|c|c|c|c|c|c|c|c|}
\hline & (1) & (2) & (3) & (4) & (5) & (6) & (7) & (8) \\
\hline & ICSN_uk & ICSN_uk & ICSN_uk & ICSN_uk & ICSN_uk & ICSN_uk & ICSN_uk & ICSN_uk \\
\hline \multirow[t]{2}{*}{$\mathrm{BDP}$} & $0.644 * * *$ & -0.039 & $0.345^{* *}$ & 0.392 & $0.594 * * *$ & -0.304 & $0.334 * *$ & 0.365 \\
\hline & $(0.001)$ & $(0.947)$ & $(0.014)$ & $(0.429)$ & (0.004) & $(0.554)$ & $(0.017)$ & $(0.457)$ \\
\hline \multirow[t]{2}{*}{ INTRATE } & $1.270 * *$ & -1.112 & & & 1.062 & -2.589 & & \\
\hline & $(0.042)$ & $(0.571)$ & & & $(0.136)$ & $(0.150)$ & & \\
\hline \multirow[t]{2}{*}{ MICSN_zg(t-1) } & $0.406^{* * * *}$ & -0.308 & & & $0.425^{* * *}$ & $-1.349 * * *$ & & \\
\hline & $(0.000)$ & $(0.205)$ & & & $(0.000)$ & $(0.003)$ & & \\
\hline \multirow[t]{2}{*}{ DEVDEPOZIT } & 0.023 & & -0.067 & & 0.013 & & -0.063 & \\
\hline & $(0.753)$ & & $(0.249)$ & & $(0.856)$ & & $(0.278)$ & \\
\hline \multirow[t]{2}{*}{$\mathrm{D}$} & $2.989^{*}$ & $6.977 * * *$ & 1.524 & 2.334 & 2.491 & $3.805^{* * *}$ & 1.243 & 2.518 \\
\hline & $(0.097)$ & $(0.004)$ & $(0.158)$ & $(0.338)$ & $(0.297)$ & $(0.050)$ & $(0.315)$ & $(0.200)$ \\
\hline \multirow[t]{2}{*}{ CONSTRCOST } & 0.006 & 0.080 & -0.020 & -0.075 & -0.002 & 0.213 & -0.019 & -0.063 \\
\hline & $(0.915)$ & $(0.684)$ & $(0.625)$ & $(0.614)$ & $(0.971)$ & $(0.203)$ & $(0.626)$ & $(0.668)$ \\
\hline \multirow[t]{2}{*}{ MBUILDPERM } & 0.045 & $0.057^{*}$ & 0.001 & 0.003 & & & & \\
\hline & $(0.151)$ & $(0.070)$ & $(0.956)$ & $(0.933)$ & & & & \\
\hline \multirow[t]{2}{*}{ NPL } & $-0.096^{* *}$ & -0.208 & $-0.063^{*}$ & -0.083 & $-0.114 * *$ & 0.077 & -0.058 & -0.137 \\
\hline & $(0.049)$ & $(0.119)$ & $(0.073)$ & $(0.540)$ & $(0.038)$ & $(0.637)$ & $(0.105)$ & $(0.401)$ \\
\hline \multirow[t]{2}{*}{ INTDEVDEP } & & 2.238 & & 0.543 & & $19.702 * * *$ & & -1.067 \\
\hline & & $(0.391)$ & & $(0.732)$ & & $(0.003)$ & & $(0.755)$ \\
\hline \multirow[t]{2}{*}{ ICSN_zg(t-1) } & & & $0.478 * * *$ & $0.587 * *$ & & & $0.472 * * *$ & $0.618 * * *$ \\
\hline & & & $(0.000)$ & $(0.016)$ & & & $(0.000)$ & $(0.005)$ \\
\hline \multirow[t]{2}{*}{ STAMKRED } & & & $0.164 * * *$ & 0.050 & & & $0.160 * * *$ & 0.074 \\
\hline & & & $(0.004)$ & $(0.642)$ & & & $(0.004)$ & $(0.488)$ \\
\hline \multirow[t]{2}{*}{ HPBUILDPERM } & & & & & 0.023 & $1.981^{* * *}$ & 0.022 & -0.194 \\
\hline & & & & & $(0.775)$ & $(0.005)$ & $(0.644)$ & $(0.602)$ \\
\hline \multirow[t]{2}{*}{ _cons } & $-6.363^{*}$ & -0.727 & -0.061 & -1.852 & -5.180 & $-20.651^{* *}$ & 0.081 & 0.604 \\
\hline & $(0.064)$ & $(0.911)$ & $(0.897)$ & $(0.639)$ & $(0.214)$ & $(0.035)$ & $(0.886)$ & $(0.919)$ \\
\hline $\mathrm{N}$ & 66 & 31 & 66 & 31 & 66 & 31 & 66 & 31 \\
\hline aic & 347.810 & 142.549 & 305.986 & 136.352 & 350.127 & 135.835 & 305.740 & 135.969 \\
\hline $\mathrm{r} 2$ & 0.849 & 0.816 & 0.920 & 0.850 & 0.844 & 0.852 & 0.920 & 0.851 \\
\hline r2_a & 0.828 & 0.750 & 0.909 & 0.795 & 0.822 & 0.798 & 0.909 & 0.797 \\
\hline
\end{tabular}

Napomena: p-vrijednosti u zagradama, statistička signifikantnost je označena kako slijedi: * p<.10, ** p<.05, $* * * \mathrm{p}<.01$.

Izvor: procjena autora.

za BDP je statistički nesignifikantna. Subvencije za stambene kredite su statistički značajne samo u dva od osam modela i u oba slučaja imaju poprilično snažan utjecaj, ali kao što se vidi ne pretjerano robustan kroz različite specifikacije ponude i potražnje. Od ostalih varijabli interesantan je negativan utjecaj loših kredita u gotovo svim specifikacijama koje su procijenjene na podacima za cijelu Hrvatsku.

Kada promotrimo rezultate samo za Grad Zagreb, tada se u kvalitativnom smislu rezultati bitno mijenjaju. Vremenski pomak zavisne varijable je ponovno statistički signifikantan u gotovo svim specifikacijama kao pomični prosjek i kao vremenski pomak (Tablica 3). Kao i za cijelu Hrvatsku, rezultati pokazuju kako su BDP i masa stambenih kredita značajni u svim 
Tablica 3: Regresijski modeli za Zagreb

\begin{tabular}{|c|c|c|c|c|c|c|c|c|}
\hline & $\begin{array}{c}(1) \\
\text { ICSN_zg }\end{array}$ & $\begin{array}{c}(2) \\
\text { ICSN_zg }\end{array}$ & $\begin{array}{c}(3) \\
\text { ICSN_zg }\end{array}$ & $\begin{array}{c}(4) \\
\text { ICSN_zg }\end{array}$ & $\begin{array}{c}(5) \\
\text { ICSN_zg }\end{array}$ & $\begin{array}{c}\text { (6) } \\
\text { ICSN_zg }\end{array}$ & $\begin{array}{c}(7) \\
\text { ICSN_zg }\end{array}$ & $\begin{array}{c}(8) \\
\text { ICSN_zg }\end{array}$ \\
\hline \multirow[t]{2}{*}{ BDP } & $0.864 * * *$ & 0.411 & $0.485^{* * *}$ & 0.369 & $0.775^{* * *}$ & 0.249 & $0.462 * * *$ & 0.227 \\
\hline & $(0.000)$ & $(0.444)$ & $(0.005)$ & $(0.381)$ & $(0.002)$ & $(0.580)$ & $(0.008)$ & $(0.574)$ \\
\hline \multirow[t]{2}{*}{ INTRATE } & $1.341^{* *}$ & -2.118 & & & 1.039 & $-2.608^{*}$ & & \\
\hline & $(0.044)$ & $(0.234)$ & & & $(0.201)$ & $(0.089)$ & & \\
\hline \multirow[t]{2}{*}{ MICSN_zg(t-1) } & $0.357 * * *$ & -0.147 & & & $0.356^{* * *}$ & $-1.008^{* * *}$ & & \\
\hline & $(0.003)$ & $(0.339)$ & & & $(0.005)$ & $(0.000)$ & & \\
\hline \multirow[t]{2}{*}{ DEVDEPOZIT } & -0.064 & & $-0.162 * *$ & & -0.070 & & $-0.161 * *$ & \\
\hline & $(0.452)$ & & $(0.026)$ & & $(0.436)$ & & $(0.029)$ & \\
\hline \multirow[t]{2}{*}{ D } & $5.668 * * *$ & $10.184^{* * * *}$ & $3.583 * *$ & $4.887 * *$ & 4.756 & $7.151 * * *$ & $3.373^{* *}$ & $3.742 * *$ \\
\hline & $(0.010)$ & $(0.000)$ & $(0.013)$ & $(0.048)$ & $(0.105)$ & $(0.000)$ & $(0.038)$ & $(0.043)$ \\
\hline \multirow[t]{2}{*}{ CONSTRCOST } & 0.035 & 0.295 & -0.022 & -0.004 & 0.026 & $0.413 * * *$ & -0.030 & 0.009 \\
\hline & $(0.589)$ & $(0.114)$ & $(0.678)$ & $(0.979)$ & $(0.706)$ & $(0.008)$ & $(0.557)$ & $(0.945)$ \\
\hline \multirow[t]{2}{*}{ MBUILDPERM } & $0.081 * *$ & $0.073 * *$ & 0.019 & 0.030 & & & & \\
\hline & $(0.028)$ & $(0.014)$ & $(0.500)$ & $(0.320)$ & & & & \\
\hline \multirow[t]{2}{*}{ NPL } & -0.067 & -0.190 & -0.057 & -0.055 & -0.106 & 0.127 & -0.062 & -0.192 \\
\hline & $(0.248)$ & $(0.124)$ & $(0.161)$ & $(0.649)$ & (0.109) & $(0.387)$ & $(0.144)$ & $(0.172)$ \\
\hline \multirow[t]{2}{*}{ INTDEVDEP } & & 3.714 & & 0.668 & & $21.813^{* * *}$ & & -3.471 \\
\hline & & $(0.123)$ & & $(0.639)$ & & $(0.000)$ & & $(0.284)$ \\
\hline \multirow[t]{2}{*}{ ICSN_zg(t-1) } & & & $0.420 * * *$ & $0.560 * * *$ & & & $0.445^{* * *}$ & $0.743 * * *$ \\
\hline & & & $(0.002)$ & $(0.006)$ & & & $(0.001)$ & $(0.000)$ \\
\hline \multirow[t]{2}{*}{ STAMKRED } & & & $0.193 * * *$ & 0.003 & & & $0.184 * * *$ & 0.061 \\
\hline & & & $(0.001)$ & $(0.978)$ & & & $(0.002)$ & $(0.523)$ \\
\hline \multirow[t]{2}{*}{ HPBUILDPERM } & & & & & 0.050 & $2.160 * * *$ & 0.013 & -0.461 \\
\hline & & & & & $(0.597)$ & $(0.000)$ & $(0.823)$ & $(0.186)$ \\
\hline \multirow[t]{2}{*}{ _cons } & $-6.690^{*}$ & 0.545 & -0.104 & -2.217 & -4.862 & $-24.612 * * *$ & -0.063 & 4.522 \\
\hline & $(0.074)$ & $(0.926)$ & $(0.855)$ & $(0.533)$ & $(0.317)$ & $(0.009)$ & $(0.927)$ & $(0.417)$ \\
\hline $\mathrm{N}$ & 66 & 31 & 66 & 31 & 66 & 31 & 66 & 31 \\
\hline aic & 370.218 & 137.030 & 333.430 & 128.634 & 375.557 & 127.895 & 333.902 & 127.542 \\
\hline $\mathrm{r} 2$ & 0.826 & 0.918 & 0.901 & 0.937 & 0.812 & 0.939 & 0.900 & 0.940 \\
\hline r2_a & 0.802 & 0.888 & 0.887 & 0.915 & 0.785 & 0.917 & 0.886 & 0.918 \\
\hline
\end{tabular}

Napomena: p-vrijednosti u zagradama, statistička signifikantnost je označena kako slijedi: * p<.10, ** p<.05, $* * * \mathrm{p}<.01$.

Izvor: procjena autora.

modelima koji su procijenjeni na 66 opservacija. Na podacima za grad Zagreb, udio loših kredita poslovnih banaka je statistički nesignifikantan u svih osam procjena, a s druge strane binarna (indikatorska) varijabla (D) je statistički značajna u sedam od osam modela.

U odnosu na podatke za cijelu Hrvatsku, utjecaj subvencija stambenih kredita na cijene stanova je u Zagrebu različit po statističkoj signifikantnosti, ali isto tako i po apsolutnoj veličini utjecaja. Procijenjeni koeficijenti koji se kreću od 3,4 do 10,2 ukazuju kako je u razdoblju nakon uvođenja stambenih subvencija došlo do snažnog, a ekonomskim fundamentima neobjašnjenog povećanja međugodišnje stope rasta stambenih nekretnina u Zagrebu za 3 do 10 postotnih bodova godišnje. 
Kada promotrimo podatke za Jadran, izvjesno je da sve promatrane domaće makroekonomske varijable ne igraju značajnu ulogu u određivanju cijena stambenih nekretnina (Tablica 3). Procjene su manje robusne od oba gore prezentirana modela, kretanje cijena je manje autokorelirano. BDP i udio loših kredita također određuju kretanje cijena u određenoj mjeri, ali je razina značajnosti navedenih varijabli manja od prethodnih varijabli. U oba modela u kojima je utjecaj procijenjen na većem uzorku, utjecaj mase stambenih kredita je statistički značajan od nule i pozitivan.

U teoretskom smislu je bilo i za očekivati kako će potražnja za stambenim nekretninama u turistički atraktivnim područjima biti manje pod utjecajem domaćih makroeko-

Tablica 4: Regresijski model za Jadran

\begin{tabular}{|c|c|c|c|c|c|c|c|c|}
\hline & $\begin{array}{c}(1) \\
\text { ICSN__ } \\
\text { jadr }\end{array}$ & $\begin{array}{c}(2) \\
\mathrm{ICSN}_{-} \\
\text {jadr }\end{array}$ & $\begin{array}{c}(3) \\
\mathrm{ICSN}_{-} \\
\text {jadr }\end{array}$ & $\begin{array}{c}(4) \\
\text { ICSN }_{-} \\
\text {jadr }\end{array}$ & $\begin{array}{c}(5) \\
\mathrm{ICSN}_{-} \\
\text {jadr }\end{array}$ & $\begin{array}{c}\text { (6) } \\
\mathrm{ICSN}_{-} \\
\text {jadr }\end{array}$ & $\begin{array}{c}(7) \\
\text { ICSN__ } \\
\text { jadr }\end{array}$ & $\begin{array}{c}\text { (8) } \\
\mathrm{ICSN}_{-} \\
\text {jadr }\end{array}$ \\
\hline BDP & $\begin{array}{c}0.546 * * * \\
(0.007)\end{array}$ & $\begin{array}{c}0.068 \\
(0.924)\end{array}$ & $\begin{array}{l}0.302 * \\
(0.070)\end{array}$ & $\begin{array}{c}0.393 \\
(0.520)\end{array}$ & $\begin{array}{c}0.513^{* *} \\
(0.013)\end{array}$ & $\begin{array}{l}-0.161 \\
(0.822)\end{array}$ & $\begin{array}{c}0.250 \\
(0.130)\end{array}$ & $\begin{array}{c}0.354 \\
(0.557)\end{array}$ \\
\hline INTRATE & $\begin{array}{c}0.695 \\
(0.449)\end{array}$ & $\begin{array}{l}-1.019 \\
(0.669)\end{array}$ & & & $\begin{array}{c}0.461 \\
(0.615)\end{array}$ & $\begin{array}{l}-1.774 \\
(0.479)\end{array}$ & & \\
\hline MICSN_jadr(t-1) & $\begin{array}{c}0.427 * * * \\
(0.000)\end{array}$ & $\begin{array}{l}-0.190 \\
(0.560)\end{array}$ & & & $\begin{array}{c}0.455^{* * *} * \\
(0.000)\end{array}$ & $\begin{array}{l}-0.475 \\
(0.406)\end{array}$ & & \\
\hline DEVDEPOZIT & $\begin{array}{l}0.135^{*} \\
(0.060)\end{array}$ & & $\begin{array}{l}-0.031 \\
(0.665)\end{array}$ & & $\begin{array}{l}0.126^{*} \\
(0.079)\end{array}$ & & $\begin{array}{l}-0.025 \\
(0.718)\end{array}$ & \\
\hline $\mathrm{D}$ & $\begin{array}{c}1.912 \\
(0.335)\end{array}$ & $\begin{array}{l}5.417 * \\
(0.058)\end{array}$ & $\begin{array}{c}0.941 \\
(0.468)\end{array}$ & $\begin{array}{c}2.593 \\
(0.339)\end{array}$ & $\begin{array}{c}1.612 \\
(0.512)\end{array}$ & $\begin{array}{c}3.058 \\
(0.233)\end{array}$ & $\begin{array}{l}-0.121 \\
(0.936)\end{array}$ & $\begin{array}{c}2.646 \\
(0.270)\end{array}$ \\
\hline CONSTRCOST & $\begin{array}{c}0.013 \\
(0.807)\end{array}$ & $\begin{array}{l}-0.046 \\
(0.844)\end{array}$ & $\begin{array}{c}0.010 \\
(0.838)\end{array}$ & $\begin{array}{l}-0.117 \\
(0.524)\end{array}$ & $\begin{array}{c}0.008 \\
(0.885)\end{array}$ & $\begin{array}{c}0.057 \\
(0.805)\end{array}$ & $\begin{array}{l}0.008 \\
(0.854)\end{array}$ & $\begin{array}{l}-0.097 \\
(0.581)\end{array}$ \\
\hline MBUILDPERM & $\begin{array}{c}0.030 \\
(0.365)\end{array}$ & $\begin{array}{c}0.048 \\
(0.220)\end{array}$ & $\begin{array}{c}0.013 \\
(0.624)\end{array}$ & $\begin{array}{c}0.006 \\
(0.879)\end{array}$ & & & & \\
\hline NPL & $\begin{array}{l}-0.094^{*} \\
(0.076)\end{array}$ & $\begin{array}{l}-0.224 \\
(0.161)\end{array}$ & $\begin{array}{c}-0.108^{* * *} \\
(0.008)\end{array}$ & $\begin{array}{l}-0.161 \\
(0.333)\end{array}$ & $\begin{array}{c}-0.104^{*} \\
(0.073)\end{array}$ & $\begin{array}{l}-0.163 \\
(0.423)\end{array}$ & $\begin{array}{c}-0.098 * * \\
(0.011)\end{array}$ & $\begin{array}{l}-0.213 \\
(0.289)\end{array}$ \\
\hline INTDEVDEP & & $\begin{array}{c}2.173 \\
(0.493)\end{array}$ & & $\begin{array}{c}1.026 \\
(0.597)\end{array}$ & & $\begin{array}{c}8.827 \\
(0.290)\end{array}$ & & $\begin{array}{l}-0.253 \\
(0.952)\end{array}$ \\
\hline ICSN_jadr(t-1) & & & $\begin{array}{l}0.206^{*} \\
(0.059)\end{array}$ & $\begin{array}{l}0.374 * \\
(0.084)\end{array}$ & & & $\begin{array}{c}0.167 \\
(0.132)\end{array}$ & $\begin{array}{l}0.396^{*} \\
(0.055)\end{array}$ \\
\hline STAMKRED & & & $\begin{array}{c}0.286^{* * * *} \\
(0.000)\end{array}$ & $\begin{array}{c}0.074 \\
(0.576)\end{array}$ & & & $\begin{array}{c}0.283^{* * *} * \\
(0.000)\end{array}$ & $\begin{array}{c}0.099 \\
(0.455)\end{array}$ \\
\hline HPBUILDPERM & & & & & $\begin{array}{c}0.005 \\
(0.947)\end{array}$ & $\begin{array}{c}0.741 \\
(0.376)\end{array}$ & $\begin{array}{c}0.083 \\
(0.171)\end{array}$ & $\begin{array}{l}-0.154 \\
(0.735)\end{array}$ \\
\hline _cons & $\begin{array}{l}-3.395 \\
(0.482) \\
\end{array}$ & $\begin{array}{l}-0.859 \\
(0.913) \\
\end{array}$ & $\begin{array}{c}0.459 \\
(0.435) \\
\end{array}$ & $\begin{array}{l}-3.028 \\
(0.531) \\
\end{array}$ & $\begin{array}{l}-2.204 \\
(0.661) \\
\end{array}$ & $\begin{array}{l}-7.220 \\
(0.544) \\
\end{array}$ & $\begin{array}{c}1.011 \\
(0.161) \\
\end{array}$ & $\begin{array}{l}-1.051 \\
(0.886) \\
\end{array}$ \\
\hline $\mathrm{N}$ & 66 & 31 & 66 & 31 & 66 & 31 & 66 & 31 \\
\hline aic & 351.374 & 153.839 & 330.847 & 149.562 & 352.327 & 154.873 & 328.940 & 149.430 \\
\hline $\mathrm{r} 2$ & 0.859 & 0.728 & 0.897 & 0.763 & 0.857 & 0.719 & 0.900 & 0.764 \\
\hline r2_a & 0.840 & 0.629 & 0.883 & 0.677 & 0.837 & 0.617 & 0.886 & 0.678 \\
\hline
\end{tabular}

Napomena: p-vrijednosti u zagradama, statistička signifikantnost je označena kako slijedi: * p<.10, ** p<.05, $* * * \mathrm{p}<.01$.

Izvor: procjena autora. 
nomskih varijabli. U skladu je s ekonomskom teorijom očekivati kako je potražnja na tržištu apartmana i/ili kuća za odmor dominantno određena makroekonomskim varijablama iz zemalja iz kojih dominantno dolaze turisti na Jadransku obalu.

Kada analiziramo procijenjene modele za ostatak Hrvatske, u kvalitativnom smislu su procjene lošije robusnosti, ali je obrazac varijabli koji značajno djeluju na cijene djelomično sličan. BDP nije značajan prediktor cijena što u biti ukazuje kako je većina ekonomskog rasta bazirana izvan ovih područja Hrvatske. Autokoreliranost kretanja cijena je prisutna, ali je nešto manje robustan rezultat u odnosu na ostale procijenjene modele. Promatramo li udio loših kredita u ukupnim kreditnim plasmanima poslovnih banaka, izvjesno je kako

Tablica 5: Regresijski model za Hrvatsku ostalo

\begin{tabular}{|c|c|c|c|c|c|c|c|c|}
\hline & $\begin{array}{c}\text { (1) } \\
\text { ICSN_ } \\
\text { ost }\end{array}$ & $\begin{array}{c}(2) \\
\text { ICSN_ } \\
\text { ost }\end{array}$ & $\begin{array}{c}\text { (3) } \\
\text { ICSN_ } \\
\text { ost }\end{array}$ & $\begin{array}{c}\text { (4) } \\
\text { ICSN_ } \\
\text { ost }\end{array}$ & $\begin{array}{c}(5) \\
\text { ICSN_ } \\
\text { ost }\end{array}$ & $\begin{array}{c}(6) \\
\text { ICSN_ost }\end{array}$ & $\begin{array}{c}\text { (7) } \\
\text { ICSN_ } \\
\text { ost }\end{array}$ & $\begin{array}{c}\text { (8) } \\
\text { ICSN_ } \\
\text { ost }\end{array}$ \\
\hline BDP & $\begin{array}{c}0.267 \\
(0.245)\end{array}$ & $\begin{array}{l}-0.515 \\
(0.437)\end{array}$ & $\begin{array}{c}0.077 \\
(0.642)\end{array}$ & $\begin{array}{l}-0.233 \\
(0.745)\end{array}$ & $\begin{array}{c}0.275 \\
(0.248)\end{array}$ & $\begin{array}{l}-0.471 \\
(0.446)\end{array}$ & $\begin{array}{c}0.094 \\
(0.571)\end{array}$ & $\begin{array}{l}-0.320 \\
(0.668)\end{array}$ \\
\hline INTRATE & $\begin{array}{c}1.379 \\
(0.110)\end{array}$ & $\begin{array}{c}1.459 \\
(0.512)\end{array}$ & & & $\begin{array}{l}1.492 \\
(0.121)\end{array}$ & $\begin{array}{c}0.485 \\
(0.813)\end{array}$ & & \\
\hline MICSN_ost(t-1) & $\begin{array}{c}0.251 \\
(0.135)\end{array}$ & $\begin{array}{c}-0.821^{* *} \\
(0.010)\end{array}$ & & & $\begin{array}{l}0.274 * \\
(0.096)\end{array}$ & $\begin{array}{c}-1.476 * * * \\
(0.001)\end{array}$ & & \\
\hline DEVDEPOZIT & $\begin{array}{c}0.152 \\
(0.102)\end{array}$ & & $\begin{array}{l}-0.005 \\
(0.939)\end{array}$ & & $\begin{array}{c}0.140 \\
(0.127)\end{array}$ & & $\begin{array}{l}-0.006 \\
(0.928)\end{array}$ & \\
\hline $\mathrm{D}$ & $\begin{array}{c}0.581 \\
(0.774)\end{array}$ & $\begin{array}{c}5.505^{* *} \\
(0.027)\end{array}$ & $\begin{array}{l}-0.699 \\
(0.596)\end{array}$ & $\begin{array}{c}3.897 \\
(0.321)\end{array}$ & $\begin{array}{c}1.342 \\
(0.621)\end{array}$ & $\begin{array}{c}0.637 \\
(0.774)\end{array}$ & $\begin{array}{l}-0.424 \\
(0.780)\end{array}$ & $\begin{array}{c}0.445 \\
(0.885)\end{array}$ \\
\hline CONSTRCOST & $\begin{array}{c}0.008 \\
(0.892)\end{array}$ & $\begin{array}{l}-0.021 \\
(0.924)\end{array}$ & $\begin{array}{l}-0.012 \\
(0.800)\end{array}$ & $\begin{array}{c}0.002 \\
(0.991)\end{array}$ & $\begin{array}{c}0.003 \\
(0.967)\end{array}$ & $\begin{array}{c}0.071 \\
(0.711)\end{array}$ & $\begin{array}{l}-0.010 \\
(0.828)\end{array}$ & $\begin{array}{c}0.018 \\
(0.942)\end{array}$ \\
\hline MBUILDPERM & $\begin{array}{c}0.022 \\
(0.541)\end{array}$ & $\begin{array}{c}0.075 * * \\
(0.038)\end{array}$ & $\begin{array}{l}-0.009 \\
(0.749)\end{array}$ & $\begin{array}{c}0.067 \\
(0.230)\end{array}$ & & & & \\
\hline NPL & $\begin{array}{c}-0.144 * * \\
(0.011)\end{array}$ & $\begin{array}{l}-0.074 \\
(0.611)\end{array}$ & $\begin{array}{c}-0.089 * * \\
(0.027)\end{array}$ & $\begin{array}{c}0.019 \\
(0.921)\end{array}$ & $\begin{array}{c}-0.173 * * * \\
(0.009)\end{array}$ & $\begin{array}{c}0.143 \\
(0.413)\end{array}$ & $\begin{array}{c}-0.093 * * \\
(0.030)\end{array}$ & $\begin{array}{l}-0.038 \\
(0.881)\end{array}$ \\
\hline INTDEVDEP & & $\begin{array}{c}0.116 \\
(0.969)\end{array}$ & & $\begin{array}{c}0.442 \\
(0.860)\end{array}$ & & $\begin{array}{c}14.179 * * \\
(0.018)\end{array}$ & & $\begin{array}{c}0.366 \\
(0.944)\end{array}$ \\
\hline ICSN_ost(t-1) & & & $\begin{array}{c}0.362^{* * *} \\
(0.007)\end{array}$ & $\begin{array}{c}0.030 \\
(0.922)\end{array}$ & & & $\begin{array}{c}0.348 * * * \\
(0.009)\end{array}$ & $\begin{array}{c}0.257 \\
(0.324)\end{array}$ \\
\hline STAMKRED & & & $\begin{array}{c}0.172 * * * \\
(0.002)\end{array}$ & $\begin{array}{l}-0.113 \\
(0.543)\end{array}$ & & & $\begin{array}{c}0.181 * * * \\
(0.002)\end{array}$ & $\begin{array}{c}0.014 \\
(0.934)\end{array}$ \\
\hline HPBUILDPERM & & & & & $\begin{array}{l}-0.038 \\
(0.668)\end{array}$ & $\begin{array}{c}1.547 * * * \\
(0.008)\end{array}$ & $\begin{array}{l}-0.024 \\
(0.683)\end{array}$ & $\begin{array}{c}0.091 \\
(0.871)\end{array}$ \\
\hline _cons & $\begin{array}{l}-7.423 \\
(0.120) \\
\end{array}$ & $\begin{array}{l}-9.483 \\
(0.202) \\
\end{array}$ & $\begin{array}{l}-0.410 \\
(0.470) \\
\end{array}$ & $\begin{array}{l}-2.352 \\
(0.713) \\
\end{array}$ & $\begin{array}{l}-8.293 \\
(0.136) \\
\end{array}$ & $\begin{array}{c}-27.085 * * \\
(0.012) \\
\end{array}$ & $\begin{array}{l}-0.555 \\
(0.420) \\
\end{array}$ & $\begin{array}{l}-0.756 \\
(0.934) \\
\end{array}$ \\
\hline $\mathrm{N}$ & 64 & 31 & 65 & 31 & 64 & 31 & 65 & 31 \\
\hline aic & 354.538 & 150.526 & 326.645 & 161.073 & 354.759 & 146.586 & 326.570 & 163.109 \\
\hline $\mathrm{r} 2$ & 0.690 & 0.514 & 0.817 & 0.316 & 0.689 & 0.572 & 0.817 & 0.270 \\
\hline r2_a & 0.645 & 0.337 & 0.791 & 0.068 & 0.644 & 0.416 & 0.791 & 0.005 \\
\hline
\end{tabular}

Napomena:p-vrijednostiuzagradama, statističkasignifikantnostjeoznačenakakoslijedi:*p<.10, ${ }^{* *} \mathrm{p}<.05,{ }^{* * *} \mathrm{p}<.01$. Izvor: procjena autora. 
je utjecaj negativan i statistički različit od nule u svim modelima sa 60 i više opservacija u procjeni. Masa stambenih kredita je značajna i djeluje pozitivno na cijene u oba modela s većim broj opservacija.

\section{ZAKLJUČAK}

Rezultati su pokazali kako su u različitim dijelovima Hrvatske važne različite determinante cijena. Za ICSN za cijelu Hrvatsku, kao čimbenici koji objašnjavaju cijene ističu se BDP, udio loših kredita u izdanim kreditima, vremenski pomak zavisne varijable i izdani stambeni krediti. Navedene varijable su donekle značajni čimbenici cijena i u regionalnoj analizi, ali uz određene posebnosti. U Gradu Zagrebu najveći i najrobusniji utjecaj na kretanje cijena ima binarna (indikatorska) varijabla koja označava razdoblje u kojem je uveden program subvencioniranja stambenih kredita, a koja u određenim modelima objašnjava gotovo kompletan rast cijena. Autokoreliranost je jak prediktor kao i na nacionalnoj razini, BDP i stambeni krediti također, a utjecaj loših kredita nije statistički različit od nule.

Kada promatramo kretanje cijena na Jadranskoj obali zanimljivo je uočiti kako je udio loših kredita i stambenih kredita čimbenik kretanja cijena stambenih nekretnina kao i na nacionalnoj razini, ali je utjecaj BDP-a i autokoreliranosti manje robustan. U ostatku Hrvatske stambeni krediti, vremenski pomak zavisne varijable i udio loših kredita djeluju kao ključni čimbenici kretanja cijena stambenih nekretnina. BDP s druge strane nema utjecaj koji je statistički različit od nule.

Analizirani rezultati u biti ukazuju kako je u sva četiri indeksa s većom ili manjom razinom robusnosti indeks cijena stambenih nekretnina u biti iznimno autokoreliran. Odnosno, prošle vrijednosti indeksa cijena nekretnina djeluju na sadašnje vrijednosti indeksa cijena nekretnina. Objašnjenje za uočenu postojanost se u biti može naći u teoriji troška korištenja prema kojoj porast cijena nekretnina stvara očekivanje da će cijena u budućnosti još više rasti te se onda povećava potražnja za stambenim nekretninama jer je percipirani trošak vlasništva manji (rast cijena kompenzira za kamatu plaćenu na stambeni kredit). Porast potražnje naravno dovodi do rasta cijena stambenih nekretnina odnosno do samoostvarujuće prognoze. Opisani proces se u biti nastavlja sve dok neki egzogeni šok ne promijeni smjer kretanja cijena i samim time i očekivanja u suprotnom smjeru. Sukladno tome možemo zaključiti da je tržište podložno iracionalnom pretjerivanju i balonima jer se indeks cijena po inerciji sam od sebe kreće u smjeru u kojem je krenuo sve dok nema velikih egzogenih šokova. U kontekstu ekonomske teorije ovaj rezultat potvrđuje nalaz iz istraživanja Slišković (2016) kako na stambenom tržištu dominiraju adaptivna očekivanja.

Činjenica kako je utjecaj BDP-a statistički značajno različit od nule u svim modelima s iznimkom ostatka Hrvatske ukazuje na općepoznatu činjenicu kako je i rast cijena nekretnina, ali i ekonomski rast u prostornom smislu koncentriran u Gradu Zagrebu i duž jadranske obale. Povrh toga, ovaj zaključak zajedno s informacijom o visokom stupnju autokoreliranosti može biti koristan putokaz oko toga što možemo očekivati tijekom trenutnog gospodarskog usporavanja i kako će trajanje krize djelovati na relativnu snagu utjecaja adaptivnih očekivanja u odnosu na pad BDP-a.

Udio loših kredita u masi izdanih kredita je značajno predviđao kretanje cijena stambenih nekretnina u svim procjenama za Hrvatsku, Jadran i ostatak Hrvatske, ali utjecaj nije 
bio statistički različit od nule u Gradu Zagrebu. U teoriji utjecaj loših kredita prije svega djeluje na strani ponude. U uvjetima kada pada prodaja novosagrađenih stanova, dolazi do poremećaja u povratu kredita od strane investitora i građevinske industrije prema bankama. Porast loših kredita djeluje u smjeru obustavljanja gradnje novih projekata sve dok se postojeći projekti na tržištu ne prodaju. Posljedično dolazi i do pritisaka na pad cijena s ciljem da se rasprodaju neprodani stanovi i smanji udio loših kredita. Pad loših kredita koji se dogodio nakon 2015. godine očigledno je pokrenuo stvari u suprotnom smjeru te je sređivanje bilanci banaka koje je proizašlo iz rasprodaje potraživanja iz loših plasmana dovelo do oživljavanja stambene aktivnosti kako na strani ponude, tako i na strani potražnje.

Analiziramo li utjecaj binarne (indikatorske) varijable koja označava razdoblje od pokretanja subvencija za stambene kredite na kretanje cijena stambenih nekretnina, očigledno je iz procjena kako je utjecaj navedenog razdoblja koncentriran na cijene stambenih nekretnina u Gradu Zagrebu. Prema procjenama u razdoblju nakon uvođenja programa subvencioniranja, stopa rasta cijena stambenih nekretnina bila je između 3 i 10 postotnih bodova godišnje veća od onoga što impliciraju ekonomski fundamenti.

Navedeni statistički rezultat može ukazivati na činjenicu kako je upravo sustav subvencija jedan od ključnih generatora rasta cijena u Gradu Zagrebu, ali je navedeni rezultat nužno uzeti s rezervom. Uobičajen pristup procjenjivanju utjecaja programa subvencija na cijene stanova je baziran na diff-diff metodi prilikom koje se analiziraju prosječne cijene stanova prije i poslije programa subvencija, ali i unutar dva poduzorka: skupine stanova koja je kupljena pomoću subvencija i skupine stanova koja nije kupljena pomoću subvencija (tzv. „kontrolna skupina“).?

Nažalost, takva istraživačka strategija nije moguća kada radimo s indeksima cijena, ali važno je istaknuti kako rezultati u ovome radu potvrđuju nalaze u radu Kunovac i Žilić (2020) u kojem je pomoću studije događaja također utvrđen statistički značajan utjecaj programa subvencija na kretanje cijena stambenih nekretnina i to također samo u ekonomski razvijenijim područjima Republike Hrvatske. Ključna razlika u odnosu na rezultate u ovome radu je snaga utjecaja subvencija koja se kreće u blizini donje granice raspona procijenjenog u ovome radu.

Hipotezu o preslagivanju portfelja i utjecaju restrukturiranja privatnog bogatstva iz deviznih depozita prema stanovima namijenjenim kratkoročnom najmu nismo uspjeli dokazati. Jedan od ključnih razloga navedenog rezultata je vjerojatno i mali broj opservacija za kamatne stope na devizne depozite koji je u biti prepolovio naš uzorak.

Analizu u ovome radu moguće je u kvalitativnom smislu proširiti odnosno unaprijediti za čitav niz varijabli. Slišković (2019) u radu koristi i broj kućanstava, plaće, rente iz indeksa potrošačkih cijena, kratkoročne kamatne stope poslovnim subjektima, ukupan broj stambenih kvadrata na tržištu i cijenu zemljišta. Moguće je da bi dodatno uključivanje ovih varijabli dodatno moglo unaprijediti našu procjenu, iako valja istaknuti kako je i navedena procjena ipak ukazivala na potražne faktore kao dominantne u objašnjavanju cijena.

U istraživanju od Slišković (2019) su BDP, trošak korištenja kapitala i vremenski pomaknuta zavisna varijabla bile signifikantne u objašnjavanju indeksa cijena za Hrvatsku u

Braakmann i McDonald (2018) nude zanimljiv primjer korištenja diff-diff metode za procjenu utjecaja ukidanja programa subvencija najamnina u Britaniji. 
cjelini, dok je na strani ponude zabilježena autokorelacija zavisne varijable novogradnje. Kada govorimo o utjecaju kamatnih stopa na stambene kredite, Slišković (2019) u regresiju uvodi kamatnu stopu zajedno s pomakom zavisne varijable unutar troška kapitala U. Rezultat je statistički značajan, ali s predznakom koji nije u skladu s teorijom. U našoj procjeni kamatna stopa na stambene kredite je statistički nevažna za objašnjavanje zavisne varijable. Moguć razlog za razliku u procjeni može biti činjenica što smo odvojeno procijenili utjecaj kamatnih stopa i vremenskog pomaka zavisne varijable, dok je Slišković (2019) prvo konstruirala $\mathrm{U}$, a onda procijenila utjecaj troška kapitala. U svakom slučaju utjecaj kamatne stope ostaje otvoreno pitanje za buduća istraživanja.

Isto tako kao što je pokazala analiza Pregled tržišta nekretnina Republike Hrvatske 2012.-2017. (2018) u Hrvatskoj postoji snažna korelacija između broja noćenja i cijena nekretnina između jedinica lokalne samouprave, tako da vjerujemo da bi u perspektivi uključivanje navedene varijable moglo dodatno rasvijetliti utjecaj strane potražnje na domaće cijene nekretnina.

\section{POPIS LITERATURE}

1. Braakmann, Nils \& Mcdonald, Stephen. (2018). Housing subsidies and property prices: Evidence from England. Regional Science and Urban Economics. 80. 10.1016/j. regsciurbeco.2018.06.002.

2. Clark S. P., \& Coggin T. D. (2011). Was there a U.S. house price bubble? An econometric analysis using national and regional panel data. The Quarterly Review of Economics and Finance, 51(2): 189-200.

3. Coleman M. I. V., LaCour-Little M., \& Vandell K.D. (2008). Subprime lending and the housing bubble: Tail wags dog? Journal of Housing Economics, 17(4): 272-290.

4. Dajčman, S. (2019), House prices in the euro area: the fundamentals and the role of financial market stress, Ekonomski pregled, Vol. 70 No. 6, 2019.

5. DiPasquale, D. and Wheaton, W. C. (1992). 'The markets for real estate assets and space: a conceptual framework', Journal of the American Real Estate and Urban Economics Association, 20(2): 181-197.

6. Égert B., \& Mihaljek D. (2007). Determinants of house prices in central and eastern Europe. BIS Working Papers No. 236.

7. Gallin J. (2006). The Long-Run Relationship between House Prices and Income: Evidence from Local Housing Markets. Real Estate Economics, 34(3): 417-438.

8. Holly S., Pesaran M. H., \& Yamagata T. (2010). A spatio-temporal model of house prices in the USA. Journal of Econometrics, 158(1): 160-173.

9. Kunovac, Davor and Kotarac, Karlo (2019). Residential Property Prices in Croatia, No 37, Surveys, The Croatian National Bank, Croatia, https://EconPapers.repec.org/ RePEc:hnb:survey:37.

10. Kunovac, Davor, Đozović, Enes, Lukinić, Gorana and Pufnik, Andreja (2008). Use of the Hedonic Method to Calculate an Index of Real Estate Prices in Croatia, No 19, Working Papers, The Croatian National Bank, Croatia, https://EconPapers.repec.org/ RePEc:hnb:wpaper:19. 
11. Kunovac, Davor i Žilić, Ivan (2020), Home Sweet Home, The Effects of Housing Loan Subsidies on the Housing Market in Croatia, Istraživanja HNB, https://www. hnb.hr/-/w-060

12. Lovrinčević, Ž., Vizek, M. (2008). Determinante cijena nekretnina u RH i potencijalni učinci liberalizacije tržišta nekretnina, Ekonomski pregled, Vol. 59, No. 12, 2008.

13. Njuškalo (2017). Baza podatka oglasnika (Pristupano: 17. 7. 2020.)

14. Poterba J. (1984). Tax Subsidies to Owner-occupied Housing: An Asset-Market Approach. Quarterly Journal of Economics 99(4): 729-52.

15. Pregled tržišta nekretnina Republike Hrvatske 2012.-2017. (2018). Ekonomski Institut i Ministarstvo graditeljstva i prostornoga uređenja.

16. Quigley J. M. (1999). Real Estate Prices and Economic Cycles. International Real Estate Review, 2(1): 1-20.

17. Slišković, T. (2019). Modelling housing market and housing price dynamics in Croatia, 12th Economics \& Finance Conference, Dubrovnik, DOI: 10.20472/ EFC.2019.012.023

18. Slišković, T. (2016). Međuovisnost makroekonomske aktivnosti i tržišta nekretnina u Hrvatskoj, Neobjavljena doktorska disertacija.

19. Tica, J., Šagovac, M.: Analiza dinamike i strukture investicija nefinancijskih poduzeća u Republici Hrvatskoj, Zbornik radova 27. tradicionalnog savjetovanja Ekonomska politika Hrvatske u 2020. godini, Opatija, 2019., str. 42-64.

20. Vizek, M. (2010). Short-run and Long-run Determinants of House Prices in Eastern and Western European Countries, Privredna kretanja i ekonomska politika, Vol. 20, No. 125, 2010.

21. Vizek, M. i Posedel, P. (2010). House price determinants in transition and EU-15 countries, Post Communist Economies 21(3):327-343, DOI: 10.1080/14631370903090640. 